\title{
Sudden Stops and Capital Controls: When to Apply in Turkey
}

\author{
Cenk Gokce Adas ${ }^{1} \&$ F. Yesim Kartalli ${ }^{2}$ \\ ${ }^{1}$ Faculty of Economics, Istanbul University, Istanbul, Turkey \\ ${ }^{2}$ INFORCE Financial Solutions, Izmir, Turkey \\ Correspondence: Cenk Gokce Adas, Faculty of Economics, Istanbul University, Beyazit, Istanbul, 34453, Turkey. \\ Tel: 90-212-440-0000-11706. E-mail: adascg@ istanbul.edu.tr
}

Received: February 8, 2016

Accepted: March 15, 2016

Online Published: March 25, 2016

doi:10.5539/ijef.v8n4p289

URL: http://dx.doi.org/10.5539/ijef.v8n4p289

\begin{abstract}
Emerging market countries need capital inflows to finance their current account deficits since their domestic savings are not at desired levels. Foreign direct investment is the appreciated form of capital inflows. However, indirect capital inflows can also boost growth if used in a proper manner. If a country has weak fundamentals and institutional structures or there exists an external shock, speculative foreign capital can easily and rapidly fly away while leaving a financial crisis behind. In this study, we summarize the theoretical background of sudden stops, and then try to identify the sudden stops in Turkey for 1996-2009 period and question the reasons of such disruptions. We particularly focus on periods just before and after the global financial crises. To identify a sudden stop period we use "means" and "volatilities" as well as changes in capital inflows/GDP ratios. Finally, we attempt to find out inflow control mechanisms to minimize the volatility of capital movements.
\end{abstract}

Keywords: Economic impact of globalization, financial crises, financial markets, international financial policy short-term capital movement

\section{Introduction}

As financial globalization increased portfolio investments into emerging market economies, these economies benefited from expanding financing opportunities of current account deficits, and domestic expenditures. However, when the tide turned, these economies were hit by a series of crises during the 1990's and experienced deep recessions.

A common grounds among these episodes of emerging market crises is the interruptions in the international capital flows referred to as "sudden stop" in the literature, coined by Dornbusch, Goldfajn, and Valdes (1995), and gained an analytical aspect with Calvo (1998)'s article. The changes triggered by an external shock and/or the structural weaknesses peculiar to the country and observed in the current accounts due to the sudden leave of foreign investors (because of trust issues) are identified as sudden stops. However, it would not be appropriate to qualify every change in current account as a sudden stop. To define a sudden stop, the recovery due to the capital outflow in the current account reaches a certain level. There is no consensus in the literature on how to measure sudden stop.

There are no such interruptions in capital flows at crises for the developed countries and the sudden stop seems to be a fact peculiar to the emerging market economies, at least until the recent financial crisis (Note 1).

The purpose of the present study is to identify how many times and on which periods sudden stops occurred in Turkey during the last decade and discusses the reasons behind them. As Turkey was usually not treated alone in the studies conducted until today and the measures to be taken against the sudden stops were not examined in a detailed manner, this study is important for drawing attention on the gap on these subjects.

\section{Theoretical Background of Sudden Stops}

An important part of the sudden stop literature stresses the fact that emerging market economies are subject to big fluctuations in external capital supply and this situation is a result of an imperfection in the international financial markets. Calvo, Izquierdo, and Mejia (2004) and Guidotti, Sturzenegger, and Villar, (2004) can be shown as an example to studies of this opinion. Therefore, the "Wall Street" becomes either the carrier contaminating the shock or the source of the shock itself. The problems in the global financial system are affecting the developing countries' economies as external shocks and these countries are getting their shares of 
the problems of the global financial system even if they do not have any structural problems. For example, the high current deficits of the United States of America (Note 2), the recent mortgage crisis, the bankruptcy of the hedge funds (out of control) due to the risky investments they made are threatening subjects for the developing countries.

Sudden stops in capital movements can also result from the internal vulnerabilities of the countries as well as they can be external. When the investors have trust issues for any reason, the countries, which seem reluctant to solve their structural problems, may experience the fast leaving of the capital from the country. Several factors like the level increase in foreign borrowing (dollarization problem), the lack of local goods in the international commercial arena, the insufficiency of the international reserves and the important part of the short-term debts within the gross debt are increasing the vulnerability of the country.

\subsection{Sudden Stop Measures}

The changes triggered by an external shock and/or the structural weaknesses peculiar to the country and observed in the current accounts due to the sudden leave of foreign investors (because of trust issues) are identified as sudden stops. However, it would not be appropriate to qualify every change in current account as a sudden stop. To define a sudden stop, the recovery due to the capital outflow in the current account reaches a certain level. There is no consensus in the literature on how to measure sudden stop.

Hutchison and Noy (2006) examined the loss of income caused by the sudden stops and the condition for the returns in the current account was sought to be at least 3\% of the GDP. While they were identifying the recoveries corresponding to $3 \%$ of the GDP as standard sudden stop, they were mentioning big sudden stop when the same ratio was $5 \%$. To be able to define a crisis as a sudden stop, they also laid down the condition of simultaneous appearance of a money crisis.

Edwards (2005) considered the countries, which previously experienced substantial capital inflow in determining a sudden stop. He identified a sudden stop period as the sudden and big decrease of capital inflow experienced in countries, which previously witnessed huge amounts of capital inflow.

Calvo, Izquierdo, and Mejia (2004) stated that the following criteria must be satisfied in order to be able to define a capital movement as a sudden stop:

- At least one of the annual based capital flow decreases must be two standard deviations different from the average. It indicates the unexpected character of the sudden stops.

- To be able to accept the finish of a sudden stop, the annual change in the capital flow is expected to be higher than the one standard deviation of the average level. This condition indicates the resistance of the sudden stop.

- The beginning of the sudden stop is determined by the first year capital flow change, which is one standard deviation under the average.

As is understood from the above-mentioned criteria, a sudden stop period starts with the exceeding of the capital flow decrease by one standard deviation under the average level and continues with reaching of two standard deviations under the average level. In addition, for the period to finish, the change in the capital flow must be superior to average minus one standard deviation.

Significant differences can be noticed between the sudden stop notion in Calvo, Izquierdo and Mejia's study and other studies, which take into consideration the current account deficit measurement calculated after a certain amount of the GDP.

Guidotti, Sturzenegger, and Villar (2004) also studied the effects of the sudden stops on the income. They have used a similar notion to this of Calvo, Izquierdo, and Mejia (2004) but they have also included 5\% of GDP change to their criteria. This was admitted in their calculations the change situation in the current deficit on some percentage of the GDP to be able to exclude the countries, which do not permit a modification in their current deficit by using their reserves during the sudden stops.

The modelling and measuring methods in traditional sudden stop articles are based on the net capital inflow. Although gross capital inflow is used in descriptions, the researchers use net capital inflow data. As the obtained data usually indicate the net flows, handling the gross flows is considered as an unnecessary complication. Since the traditional international macro models also involve the net flows, there is no fact encouraging the researchers on gross flows. This is why net flow data is preferred in sudden stop studies. Rothenberg and Warnock (2006) expressed that a situation where the gross capital inflow decrease is presumed in the sudden stop literature but the local investors' transactions are also included in the calculations as practically only net flows are used.

Cowan, Gregorio, Micco, and Neilson (2008) suggest that the gross figures must be included in the calculations 
instead of net capital flows. In floating exchange rate regime, the returns in current account and capital account appear simultaneously, thus it becomes impossible to guess the source of the returns by observing the change in the net capital flow.

The foreign investors are blamed in most of the studies realized until now on the economic crises related to the foreign capital. With this point of view, one might get the impression that the global investors suddenly stop providing funds to the emerging market countries for a reason proper to that country or for any other indirect reason.

Rothenberg and Warnock (2006) who questioned if it would be fair to blame only the investor or if the local investors have any effects on crisis have also included the local investors' behaviors in their analysis on sudden stops. They do not deny the role of the global investor in spreading of the crisis and treat the capital outflow in two parts: true sudden stops and sudden flights. The fact they call a true sudden stop expresses the sudden leaving of the country by foreign investors and the sudden flight the pulling of the local investors out of the market. They show in their study that almost half of the crises handled in sudden stop literature were not sudden stops but sudden flights.

The local investors who are more informed than the foreign ones are able to guess in advance the negative shocks, which might affect the local market, and to leave the local market based on this information and transfer their money to the global markets. Traditional sudden stop articles are evaluating these two different effects together and are considering them all as sudden stop.

Lately, the term "capital flight" also appeared on other studies. For example Cowan and Gregorio (2006), expressed that the situation lived in Chile in 1998 was a different style of capital movement than these proper to South America and highlighted the fact that there was mostly a question of capital outflow increase rather than capital inflow decrease. The local investors were increasing their foreign asset investments.

Cowan, Gregorio, Micco, and Neilson (2008) also made a distinction between the sudden stop, the true sudden stop, and the outflow starts. Just like in the traditional literature, they are calling sudden stop the big declines in net capital inflows. When they talk about the inflow stops or true sudden stops, they refer to the big declines in gross capital inflows. In addition, the big absolute increases in the capital flows were defined as outflow starts.

\subsection{Factors Contributing to Sudden Stops}

\subsubsection{Structural Weakness}

Calvo, Izquierdo, and Mejia (2004) suggest that the fiscal discipline (Note 3) and the soft exchange rate pegs (Note 4) are not enough to explain the current crises and they draw attention to the structural weakness which turns the emerging markets fragile against the shocks and of which they suffer. They especially accentuate on the real exchange rate (the price of the foreign trade goods relative to the price of non-foreign trade goods).

The sudden stops, which will lead to important cuts in the credits, will bring along a decrease in aggregate demand and then a big increase in real exchange rate. Thus, a sudden stop will transform into a self-feeding mechanism.

The conclusions of the empirical study conducted by Calvo, Izquierdo, and Mejia (2004) support the opinion, which suggests that the real exchange rate fluctuations and the domestic exchange rate liability are between the important determinants of the sudden stop possibility.

In his study, Arteta (2003) has tried to explain the relation between domestic exchange rate liabilities and the exchange rate crises and inspected on how the financial vulnerability is affected when the foreign exchange deposits and foreign currency loans have an important place in the banking system. He could not determine a significant relation between the high exchange rate liability and the banking crisis nor the currency.

The sudden stop statistics studied by Calvo, Izquierdo, and Mejia (2004) indicate that $37 \%$ of the emerging market devaluation develops independently from the sudden stop and the same figure is $83 \%$ for the developed countries. This shows that the capital markets do not close their doors to the developed countries during the currency crises unlike the emerging markets.

\subsubsection{External Shocks}

The emerging market economies always run current deficits to be able to gain the resources they need for the growth and to maintain their consumption level. Thus, to be able to maintain the current deficits, there must be a continuous external inflow. However, it is also a common situation for the countries without structural problems to experience sudden stops. The reason for those stops is the developments in the outside world. 
Calvo (2005) points at the global capital markets as the responsible of the sudden stops formed in the emerging market economies. He says that the South American crises are related to the public debts, which are structural problems, in other words, they are in debt crises, but there is no such debt problem in emerging Asia.

\subsubsection{Openness and Crisis Probability}

There are two totally different points of view regarding whether the free movement of capital among countries triggers a crisis or not. Some suggest that the free entry and exit of capital to/from the emerging market economies disturb macroeconomic balance and increase financial vulnerability. Stiglitz (2002), for instance, holds that the liberalization of the capital account is the most important factor causing crises.

On the other hand, Edwards (2005) studied the relation between the capital movement restrictions and external crises by using many data from several countries. He especially worked on the sudden cut of the capital flow and the current account returns. He has examined the studies which try to measure the free movement scale of the capital and created a new index by joining together two of the liberty indexes formed before and some country-based information. There was no systematic finding at the end of the application, which indicates that the countries where capital has freedom of movement are subject to more crises than the others are.

Frankel and Cavallo (2004) examined the relation between the liberty of trade and sensibility against the sudden stops. They suggest that the economies trading less with other countries are more subject to sudden stops and money crises. The increase of the liberty of trade is decreasing the sudden stop probability. Increasing trade to GDP ratio by $10 \%$ can reduce the sudden stop possibility by $32 \%$ when all other variables are fixed.

\section{Empirical Analysis on Sudden Stops in Turkey and Their Side Effects}

\subsection{Determination of the Sudden Stop Period}

Certain criteria must be reached to be able to qualify a decrease in the capital flow as a sudden stop. There are several sudden stop definitions in literature as already mentioned before. Some of those suggest that the sudden stop only occurs when the size of the cut in capital flow reaches a certain ratio of the GDP while some others use methods that are more complex. To determine the sudden stop periods in Turkey, this study expects the below criteria to be reached by the capital inflow decrease:

i- The capital flow decrease at any month during the sudden stop period must be at least two standard deviations below the average. In other words, the below inequality must be provided;

Capital flow decrease $\geq$ (capital flow average $-2 \mathrm{x}$ capital flow standard deviation)

ii- The sudden stop period begins when the capital flow decrease at any month is at least one standard deviation below the average. In other words, the below inequality must be provided;

Capital flow decrease $\geq$ (capital flow average - capital flow volatility)

iii- The sudden stop period ends when the capital flow decrease at any month is at least one standard deviation above the average. In other words, the below inequality must be provided;

Capital flow decrease $\leq$ (capital flow average - capital flow volatility)

The first condition guarantees the unexpected appearance character of the sudden stop. In addition, the third condition reflects the resistant character of the sudden stops. The sudden stop period starts with second condition and ends with the third. However, it is expected for the capital inflow decrease to materialize the first condition at least once between those two dates.

To be able to add the adverse impact of the sudden stops on the economy in the criteria, it was expected for the capital flow change during the sudden stop period to reach a certain proportion of the GDP.

\subsection{Methodology}

Monthly foreign capital figures were used for the narrow and large definition data sets and one-year and two-year moving averages were used to determine the averages of the related months. Similarly, one-year and two-year moving standard deviations were calculated to be able to determine the volatility of the capital movements.

Annual-based monthly moving averages $\left(\mathrm{X}_{\mathrm{t}}\right)$ were calculated as follows:

$$
\bar{X}_{t}=\frac{X_{t_{1}}+X_{t_{2}}}{2} \quad X_{t_{1}}=\frac{\sum_{i=0}^{6} X_{t-i}+\sum_{i=1}^{5} X_{t+i}}{12} \quad X_{t_{2}}=\frac{\sum_{i=0}^{5} X_{t-i}+\sum_{i=1}^{6} X_{t+i}}{12}
$$


For example to calculate the moving average of July 1996, first the average based on data of the months in between January-December 1996 is calculated $\left(X_{t_{1}}\right)$, then the second average based on data of the months in between February 1996-January 1999 is calculated $\left(X_{t_{2}}\right)$. On the next step, the annual-based average of July 1996 is calculated out of the two averages.

The following calculations were made to find the two-year based monthly moving averages $\left(\mathrm{Y}_{\mathrm{t}}\right)$ of the each month:

$$
\bar{Y}_{t}=\frac{Y_{t_{1}}+Y_{t_{2}}}{2} \quad Y_{t_{1}}=\frac{\sum_{i=0}^{11} Y_{t-i}+\sum_{i=1}^{12} Y_{t+i}}{24} \quad Y_{t_{2}}=\frac{\sum_{i=0}^{10} Y_{t-i}+\sum_{i=1}^{13} Y_{t+i}}{24}
$$

The same average method is also used determine the one-year and two-year volatility of the related months.

\subsection{Data Set}

In Turkey, various items from the Capital and Finance Accounts from the balance of payments statistics were used to determine the sudden stops in foreign capital flow for the period in between 1996-2009. The direct foreign investments were not included in sudden stop calculations as they are usually stable and no significant connection between the sudden stops and this type of capital was confirmed. The Portfolio Investments and Other Investments were taken into consideration but the unrelated items in Other Investments, which are not directly related, were excluded.

Two data sets were created to determine the sudden stop periods. One of these was large definition and it was not screened in a detailed manner. Items presumed to represent short-term movements were included in the narrow definition.

In large definition, data set includes Portfolio Investments / Liabilities; Other Investments / Liabilities / Loans; Other Investments / Liabilities / Currency and Deposits titles of the Balance of Payments were gathered together. The instructions of the Central Bank of the Republic of Turkey (CBRT) on the said data are below:

Portfolio Investments / Liabilities: "Non-residents' security transactions in domestic markets associated with equity securities and residents' bond issues in domestic and international capital markets (for example Treasury's Eurobond issues, banks' and other sectors' bond issues in domestic and international markets) are recorded under this item." (Note 5).

Other Investments / Liabilities / Loans: "comprise the lending of funds (including the disbursements from International Monetary Fund) provided from non-residents to the residents according to the sector and maturity on borrower side." (Note 6).

Other Investments / Liabilities / Currency and Deposits: "comprise the deposit accounts of non-residents held with the CBRT and the banks. Deposit accounts held with the Central Bank of Republic of Turkey (CBRT) refer to the change in the Foreign Exchange Deposit Accounts with Credit Letters and Super Foreign Exchange Accounts belonging to Turkish citizens residing abroad, while the deposits held within the banks reflect the change in the Foreign Exchange and Turkish Lira deposits of the non-resident persons and banks." (Note 7).

Although the "Liabilities" item of the portfolio investments was included in the calculation as is in the large definition of the data set, the Trade Credits were excluded from the liabilities on other investments item. Under commercial loans are followed the import and export loans and the capital movements due to the foreign trade are not included in the study as they are not in its scope.

In the narrow definition data set, the liabilities part was totally included as it indicates the capital movements of the foreigners of whom the portfolio investments are presumed to be short termed. In Loans subheading studied under Other Investments heading are displayed the loans that the Central Bank and the government borrowed from the International Money Fund and paid back and the other short and long term loans provided from other resources. As the sudden stops are mostly related with the short-term capital movements, the long-term loans were also excluded from the study. The short-term loans used by the Central Bank and the government were excluded from the calculations as they are negligible measures. Only the short-term loans that the banks got from abroad were included in the calculations. 
Another item included in the narrow definition foreign capital calculation is the bank deposits of the abroad citizens.

The items constituting the narrow and large definition data set are displayed with their headings in the Balance of Payments Detailed Presentation in Table 1:

Table 1. Summary of data sets

\begin{tabular}{ll}
\hline Large Definition Data Set & Narrow Definition Data Set \\
\hline Portfolio Investments-Liabilities & Portfolio Investments- Liabilities \\
Other Investments- Liabilities-Loans & Other Investments- Liabilities-Loans -Banks-Short Term \\
Other Investments- Liabilities-Currency and Deposits & Other Investments- Liabilities-Currency and Deposits -Banks \\
\hline
\end{tabular}

Source: Central Bank of Republic of Turkey, Balance of Payment Statistics, Definition, Principles, and Practice in Turkey, Statistics Department, Balance of Payment Division, 2007.

\subsection{Identifying Sudden Stop Periods}

We first looked for the potential periods satisfying the three conditions mentioned in the section 'Determination of the Sudden Stop Period'. We have determined that August-September 1998, March 2003 and May 2006 periods providing the three conditions of the sudden stop when large definition data set and annual average and standard deviation calculation method is used (Figure 1).

When we took into consideration the two-year moving averages and standard deviations, the candidate sudden stop period number increased to five; August-October 1998, November 2000, March 2003, October-November 2003 and May 2006 (Figure 2).

In addition, with the narrow definition data set, the one-year moving averages and volatilities show that there is only one period (May 2006) providing the three conditions of the sudden stop (Figure 3).

When the same analysis is repeated by using the two-year moving averages and volatilities, 4 periods providing the first three conditions of the sudden stop stand out. As it can also be observed in the Figure 4, the foreign capital figures concerning August-October 1998, November 2000, February 2001, and May 2006 had values two standard deviants below the average.

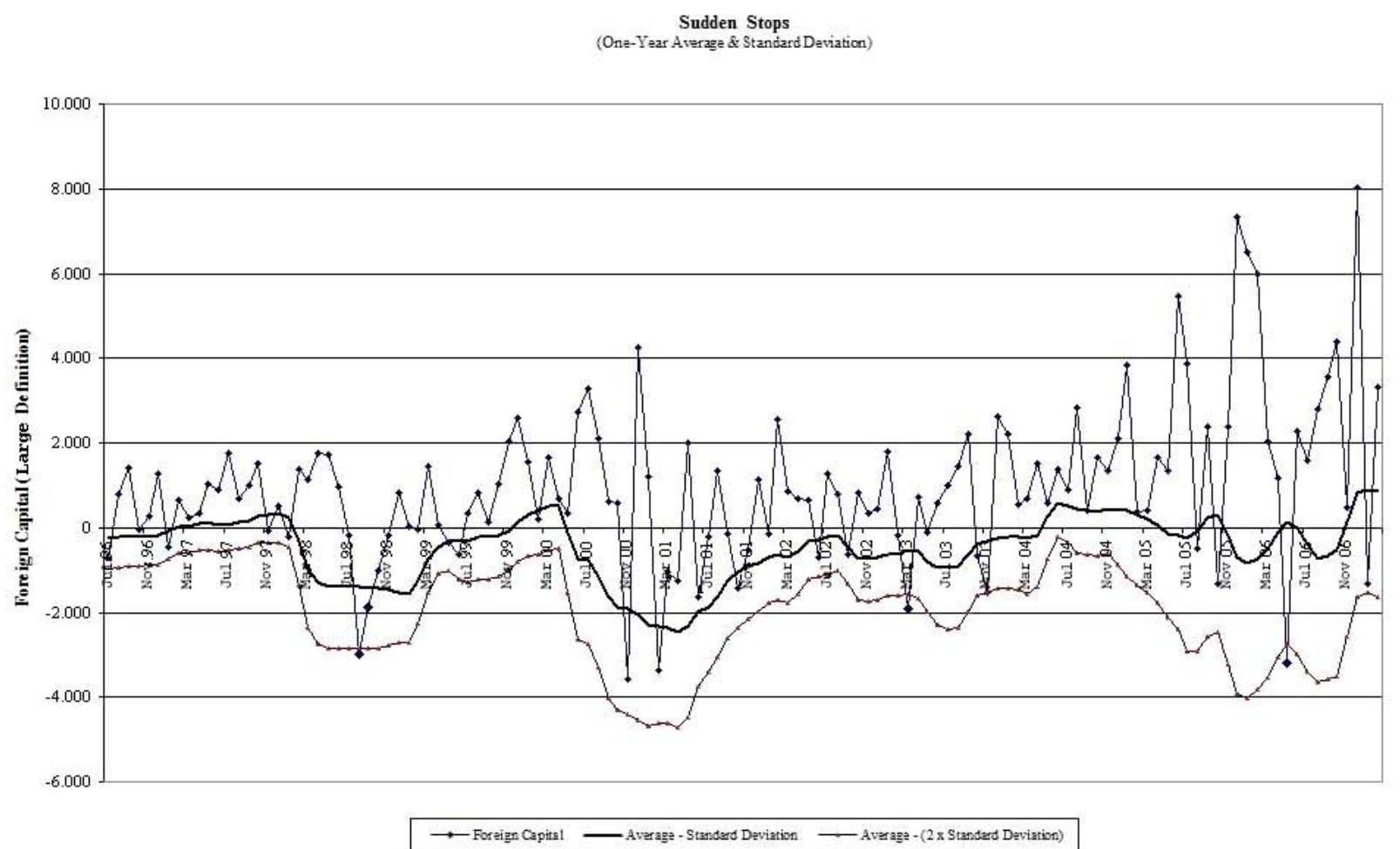

Figure 1. Sudden stop (foreign capital large definition-annual) 
Sudden Stops

(Two-Year Average \& Standard Deviation)

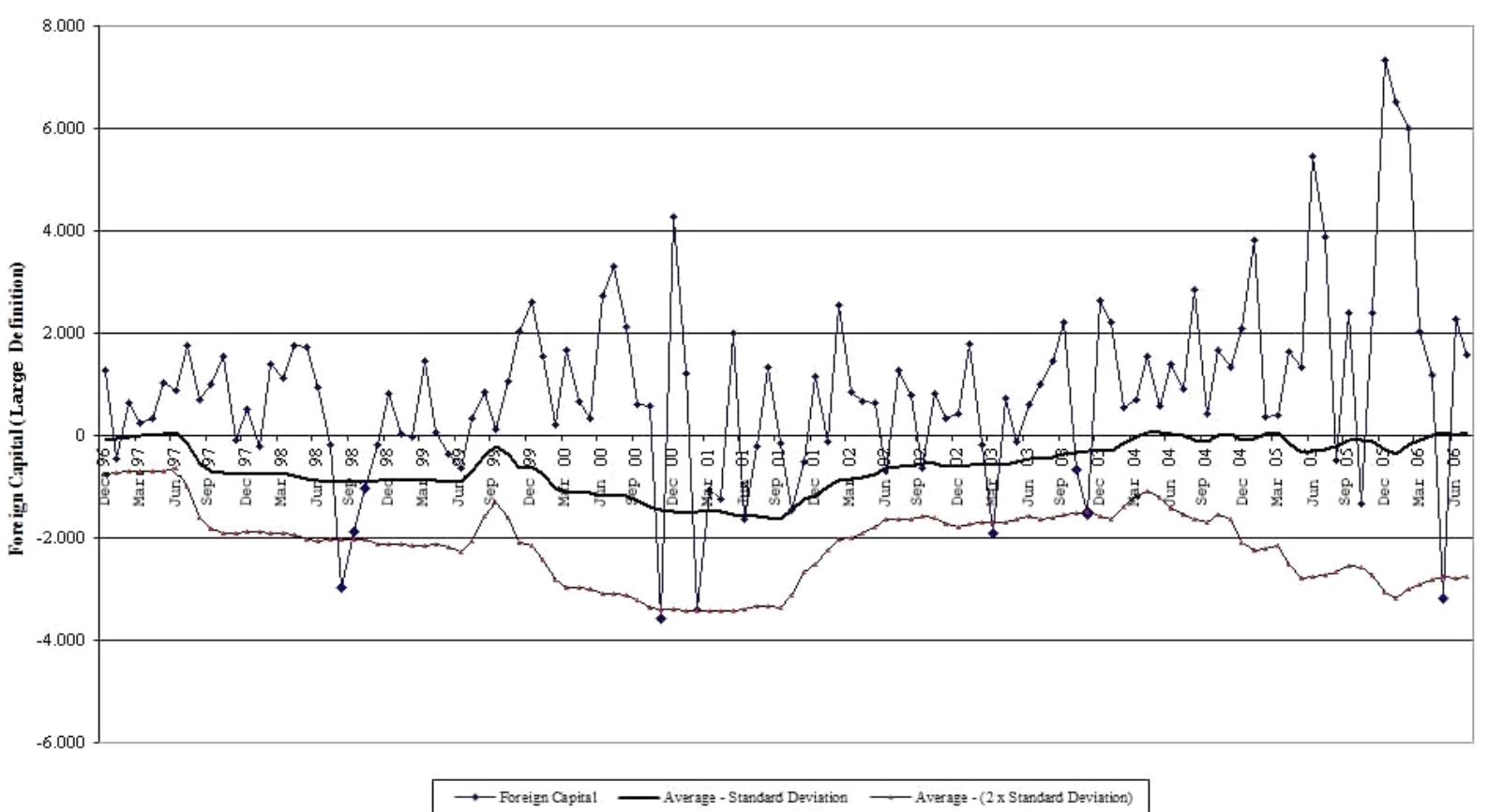

Figure 2. Sudden stop (foreign capital large definition-biannual)

Sudden Stops

(One-Year Average \& Standard Deviation)

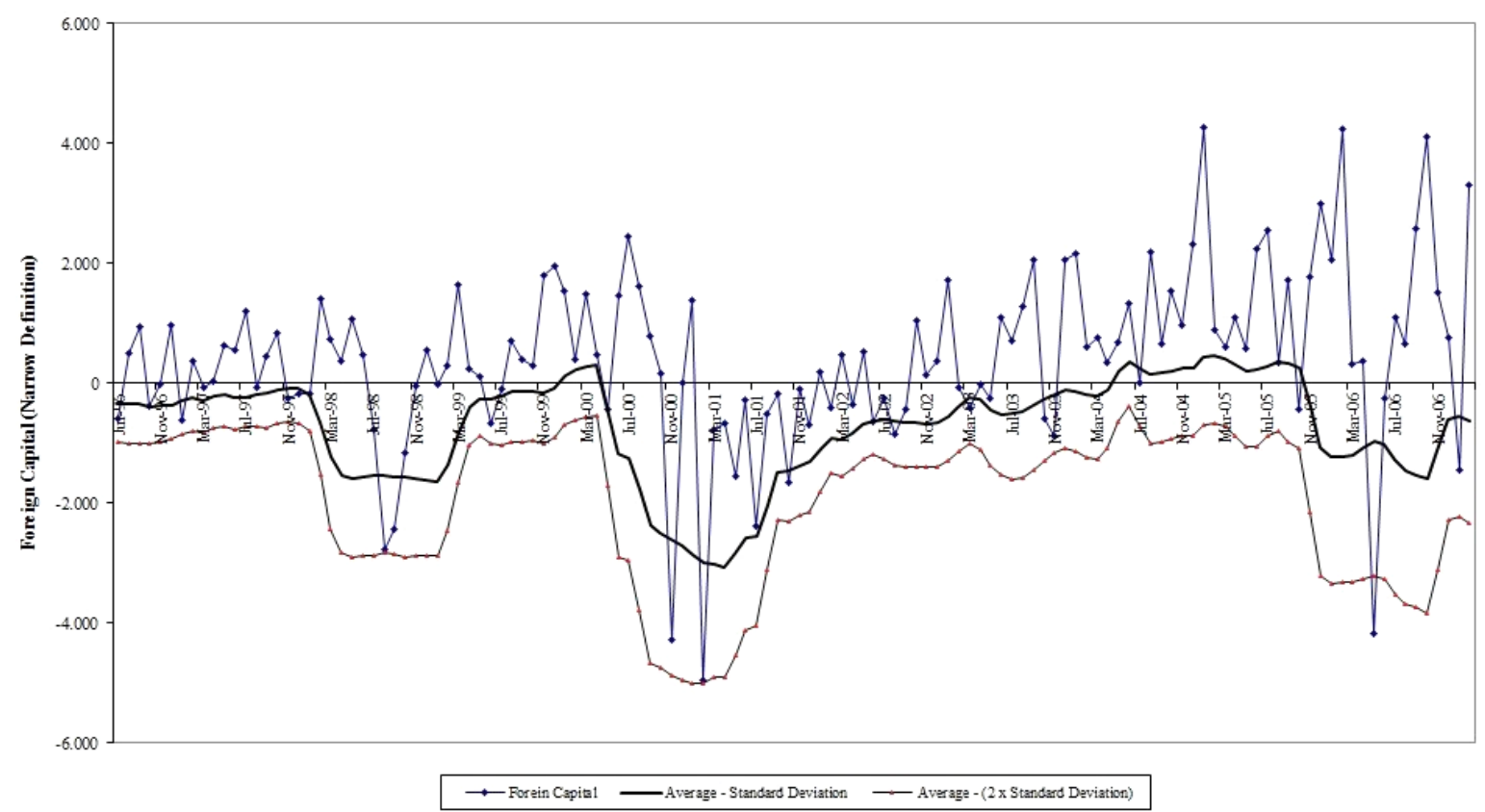

Figure 3. Sudden stop (foreign capital narrow definition -annual) 


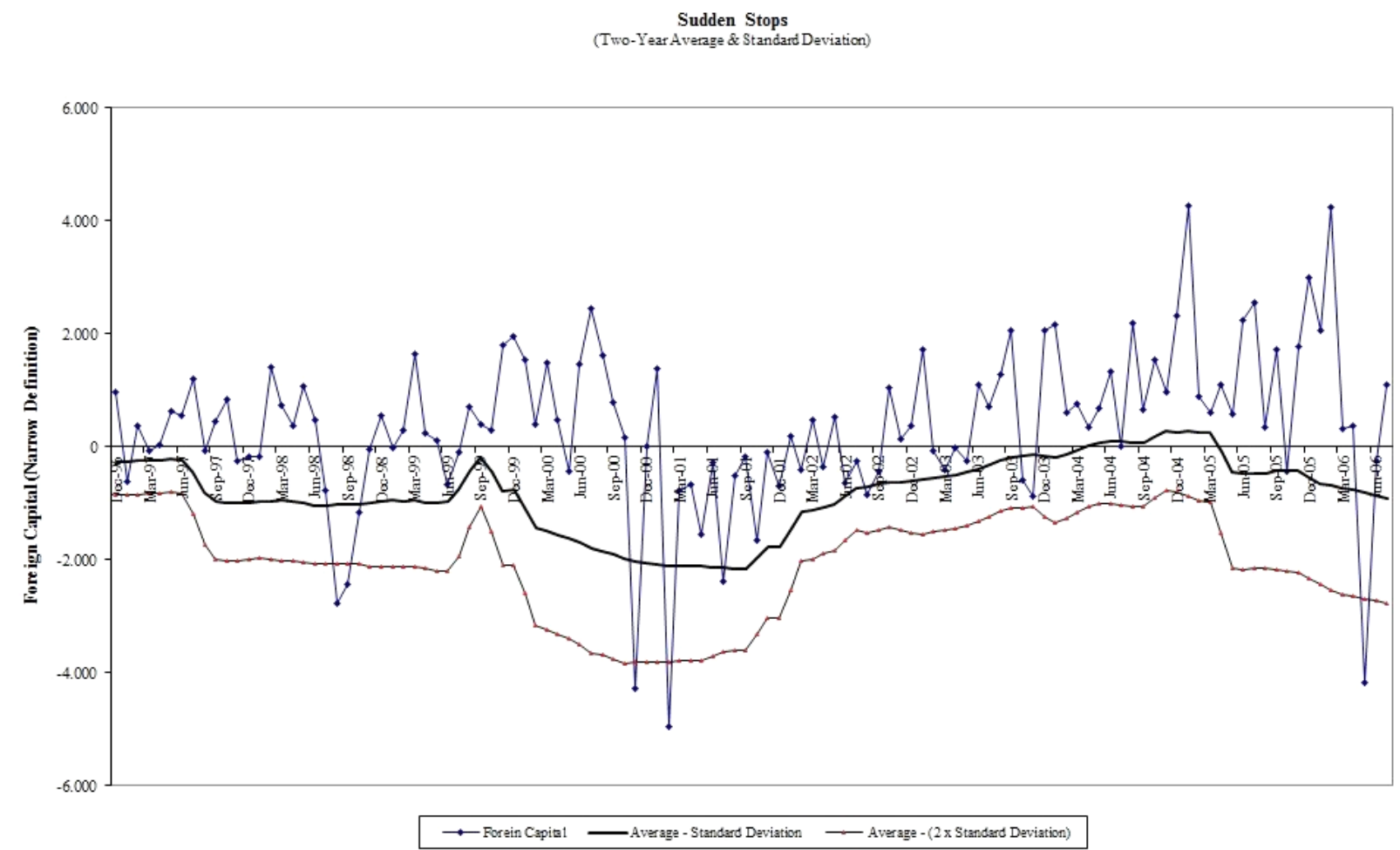

Figure 4. Sudden stop (foreign capital narrow definition-biannual)

To be able to display whether foreign capital flows in the above mentioned periods constitute a sudden stop, we have calculated the rate of the capital movements in the said periods to the GDP (Note 8) (Table 2 and Table 3).

Table 2. Foreign capital (large definition) and its ratio to GDP

\begin{tabular}{lcc}
\hline & $\begin{array}{c}\text { Foreign Capital } \\
\text { (large definition)(million \$) }\end{array}$ & $\begin{array}{c}\text { Ratio to GDP } \\
(\%)\end{array}$ \\
\hline August 1998 & $-2,974$ & -4.73 \\
September 1998 & $-1,883$ & -2.99 \\
October 1998 & $-1,022$ & -1.94 \\
November 2000 & $-3,576$ & -6.79 \\
March 2003 & $-1,920$ & -4.60 \\
October 2003 & -681 & -1.01 \\
November 2003 & $-1,527$ & -2.26 \\
May 2006 & $-3,187$ & -3.47 \\
\hline
\end{tabular}

Table 3. Foreign capital (narrow definition) and its ratio to GDP

\begin{tabular}{lcc}
\hline & $\begin{array}{c}\text { Foreign Capital } \\
\text { (narrow definition)(million \$) }\end{array}$ & $\begin{array}{c}\text { Ratio to GDP } \\
(\%)\end{array}$ \\
\hline August 1998 & $-2,770$ & -4.40 \\
September 1998 & $-2,430$ & -3.86 \\
October 1998 & $-1,158$ & -2.20 \\
November 2000 & $-4,279$ & -8.13 \\
February 2001 & $-4,943$ & -15.44 \\
May 2006 & $-4,162$ & -4.53 \\
\hline
\end{tabular}

Five periods with sudden stop criteria and corresponding to 3\% of the GDP and two periods corresponding to 5\% of the GDP in between January 1996 - July 2009 come to prominence. August-October 1998, November 2000, 
February 2001, March 2003, and May 2006 periods can be qualified as sudden stops when taking 3\% of the GDP into consideration. Moreover, when taking 5\% of the GDP into consideration, November 2000 and February 2001 can be qualified as sudden stops. The sudden stop periods defined with the combined evaluation of the foreign capital definitions, annual- biannual average and volatility definitions and 3\% and 5\% of the GDP criteria are shown in Table 4.

Table 4. Sudden stop periods according to certain criteria

\begin{tabular}{|c|c|c|c|c|c|c|c|}
\hline \multicolumn{4}{|l|}{ Large Definition } & \multicolumn{4}{|c|}{ Narrow Definition } \\
\hline Annual & & Biannual & & Annual & & Biannual & \\
\hline GDP $\% 3$ & GDP $\% 5$ & GDP $\% 3$ & GDP $\% 5$ & GDP $\% 3$ & GDP $\% 5$ & GDP $\% 3$ & GDP $\% 5$ \\
\hline August-Sept.1998 & - & August-Oct. 1998 & Nov. 2000 & May 2006 & - & August -Oct. 1998 & Nov. 2000 \\
\hline March 2003 & - & Nov. 2000 & & & & Nov. 2000 & Feb. 2001 \\
\hline May 2006 & - & March 2003 & & & & Feb. 2001 & \\
\hline & & May 2006 & & & & May 2006 & \\
\hline
\end{tabular}

As it can be observed on Table 4, while there were only three sudden stops according to 3\% of the GDP criteria when annual-based average and volatility calculations are made and large definition capital movement is handled, there were no sudden stops observed when the criteria was raised up to 5\% of the GDP. Moreover, when biannual average and volatility figures were used, there were four sudden stops responding to $3 \%$ of the GDP criteria and one sudden stop responding to the 5\% of the GDP criteria according to the large-scale data set.

When the narrow definition data set was taken into consideration, the annual average and standard deviations and 3\% of the GDP criteria pointed at one sudden stop, while no periods with 5\% of the GDP criteria could be determined. With biannual average and standard deviations, at least four sudden stops according to $3 \%$ of the GDP criteria determined, while this number was only two according to 5\% of the GDP criteria.

Although the February 2001 sudden stop period takes place in narrow definition, it could not be defined as a sudden stop in the analysis made with the large definition capital inflow. While the shedding of the open positions by the banks was taken into consideration in small definition, the position shedding of the banks was balanced by the 1.4 billion $\$$ help made in February 2001 as in the large scale definition there are IMF loans together with the open positions of the banks. The large definition had a hiding effect concerning the decrease in the banks' short-term loans (Table 5).

The reason for the March 2003 period to appear in the large definition but not the narrow one is due to the long-term credits of the sectors other than banking. Therefore the said difference is a result of the 1.8 billion \$ payback of the long-term loans to the other sectors in March 2003 (Table 5).

Table 5. Sub-details of the capital movements in February 2001 and March 2003 (million \$)

\begin{tabular}{lcccc}
\hline Balance of Payment Items & \multicolumn{2}{c}{ February 2001 } & \multicolumn{2}{c}{ March 2003 } \\
\cline { 2 - 5 } & Narrow Definition & Large Definition & Narrow Definition & Large Definition \\
\hline Liabilities & $-3,394$ & $-3,394$ & -978 & -978 \\
Loans & & 285 & & $-1,145$ \\
Deposits & & -271 & & 204 \\
Banks/Short Term & $-1,278$ & & 384 & \\
Banks & -271 & & 184 & $-1,919$ \\
Total & $-4,943$ & $-3,380$ & -410 & \\
\hline
\end{tabular}

\subsection{Reserve Status in Sudden Stop Period}

As some countries chose to control on the capital to correct the negative effects appeared in macroeconomic measures after the foreign capital left the developing countries for internal factors or external shocks, some others preferred to use the funds provided by IMF during the crisis periods. Many of the emerging market economies started saving international reserves when they realized that the existence of enough liquidity in the market during the crisis is an important factor to rebuild up the investor's trust.

Table 6 and Table 7 indicate the change in gross currency reserves of Turkey when the foreign capital intensely 
left the country. In other words, they display how much currency was put on the market by the Central Bank.

Table 6. Foreign capital (large definition) and change in the reserve

\begin{tabular}{lcc}
\hline & $\begin{array}{c}\text { Foreign Capital } \\
\text { (large definition)(million \$) }\end{array}$ & $\begin{array}{c}\text { Change in the Reserve } \\
\text { (million \$) }\end{array}$ \\
\hline August 1998 & $-2,974$ & $-3,846$ \\
September 1998 & $-1,883$ & -308 \\
October 1998 & $-1,022$ & -591 \\
November 2000 & $-3,576$ & $-4,725$ \\
March 2003 & $-1,920$ & $-1,149$ \\
May 2006 & $-3,187$ & -39 \\
\hline
\end{tabular}

Table 7. Foreign capital (narrow definition) and change in the reserve

\begin{tabular}{lcc}
\hline & $\begin{array}{c}\text { Foreign Capital } \\
\text { (narrow definition)(million \$) }\end{array}$ & $\begin{array}{c}\text { Change in the Reserve } \\
\text { (million \$) }\end{array}$ \\
\hline August 1998 & $-2,770$ & $-3,846$ \\
September 1998 & $-2,430$ & -308 \\
October 1998 & $-1,158$ & -591 \\
November 2000 & $-4,279$ & $-4,725$ \\
March 2003 & $-4,943$ & $-3,332$ \\
May 2006 & $-4,162$ & -39 \\
\hline
\end{tabular}

The Central Bank has used some of its reserves during sudden stop periods but this part was not enough to calm down the markets. The reserve level of the Central Bank and the used amount at the leaving moment of the investors are indicated in Table 8.

Table 8. Gross currency reserve and reserve usage

\begin{tabular}{lcc}
\hline & $\begin{array}{c}\text { Gross Currency Reserve } \\
\text { (million \$) }\end{array}$ & $\begin{array}{c}\text { Reserve Usage } \\
(\%)\end{array}$ \\
\hline August 1998 & 21,865 & 17.59 \\
September 1998 & 21,557 & 1.43 \\
October 1998 & 20,965 & 2.82 \\
November 2000 & 18,820 & 25.11 \\
February 2001 & 21,432 & 15.55 \\
March 2003 & 26,548 & 4.33 \\
May 2006 & 59,714 & 0.07 \\
\hline
\end{tabular}

When the reserve usage rate is checked, we can observe that the Central Bank preferred to use $25 \%$ and $16 \%$ of its reserves during November 2000 and February 2001 crises respectively. These crises are ranked between Turkey's most important crises.

\subsection{Internal and External Developments in Sudden Stop Periods}

\subsubsection{August-October 1998}

The Russian Crisis and the Almost Bankruptcy of the Long Term Capital Management Fund

During the summer of 1998, the flight from Rouble has started in Russia who was financially quite weakened and when no aid came from the west, the money crisis and the debt moratorium were next on the agenda. A crisis, which occurs in a developing country, has directed the foreign investors to revise their positions in countries in similar classification and to leave the risky regions for safer economies. The risk premium has increased in both developed and developing countries.

Another group of actors affected by the Russian crisis was the hot money managing corporations called hedge 
funds. The gradually increasing competition between the hedge funds caused to the decrease in the profit margin and the moving of those corporations towards more risky regions and investments.

The Long Term Capital Management Fund (LTCM) was an American hedge fund which had 125 billion \$ assets in as per July 1998 and which was financing 4.1 billion \$ of these assets with its own resources and the others by borrowing. LTCM who was working with high profits had 50,000 derivative contracts with nominal value of 1 trillion \$. It was managed as a fund which invests by using the state bonds of the United States of America, Japan, and European countries and which tries to profit from their arbitrage possibilities. The fund was acting in accordance with the expectation that some bonds, which are coherent with the short-term interests, will become compatible by time. When the investors who were scared after the Russian crisis sold their Japanese and European state bonds and have chosen to move towards the American bonds, which seemed more secure, the LTCM fund started making big loss. As the selling of its stocks to cover the loss might have caused a big collapse in the market, Federal Reserve Bank of New York has provided liquidity to the almost bankrupt fund by convincing some big corporations become the fund's partners. Thus, a global collapse was prevented.

\subsubsection{November 2000 and February 2001}

\section{Structural Problems}

The structural reforms work taking place in the standby arrangement signed with the IMF on 22 December 1999 was fast carried on until the first half of 2000 but in the second half it has slowed down and fall back on behind of the stabilization program. The delays in reforms, the problems in the banking sector and the intense audit of the Banking Regulation and Supervision Agency have conducted the banks to close their open positions. The excessive currency demand of the banks has also encouraged the demand for Turkish Lira and caused an increase in the interests.

In January 2001, the liquidity offer by the Central Bank to the market more than agreed in the stand-by arrangement has caused a decrease in the interests and the interests started falling under $100 \%$. On the other hand, the currency buying of the banks that became nervous by their open positions started enforcing the exchange rates. The Treasury in an effort to roll over 6 Billion $\$$ depth on $21^{\text {st }}$ of February, could raise only 0.7 Billion $\$$ despite the fact that the maturity of the bonds were as low as one month. The non-willingness of the Central Bank to compromise on its Net Internal Assets target has aggravated the liquidity problem in the market and the interests rapidly started increasing. Non-procurement of liquidity by the Central Bank to the market has deepened the crisis. On the other hand, when the Central Bank who does not want to use its reserves did not either provide the currency demanded by the market, US dollar almost gained $40 \%$ value. The currency started fluctuating after these developments and it was imperative to choose the floating exchange rate regime.

\subsubsection{March 2003}

The Refusal of 1 March resolution (Turkish Parliament to refuse to allow US troops to open a northern front for the Iraqi War in Turkish territory) and Occupation of Iraq.

The geopolitical ambiguity at the end of 2002 and the beginning of 2003 had a very negative effect on world's economy and they were perceived as a negative threat to the world's growth. The tension between the United States of America and Iraq has created an ambiguous atmosphere and triggered a disturbance in the markets. The refusal of the 1 March 2003 resolution which allowed the United States of America to use Turkish soil by Turkish Parliament and the start of the Iraqi occupation on 20 March 2003 have conducted the foreign investors to retrieve their investment from Turkey which was in the hot zone.

\subsubsection{May 2006}

\section{Global Fluctuation (Market Correction)}

The price increase in commodity markets, the augmentation in capacity usage rates, and the ascent in the salaries as of April 2006 have increased the worries of the investors and public authorities as well as the expected inflation in developed markets. The tendency of the Federal Reserve Bank and the European Central Bank to increase the interest rates has continued under the shadow of the inflation worries. The Japanese Central Bank has not changed its " 0 " interest rate but has withdrew its liquidity support from the Japanese banks to show that it might increase the interest rates in the future. The central banks of developing countries have also increased their interest rates following the developed countries' central banks (Note 9).

Those developments have conducted the investors to revise their global growth estimations. Important decreases were observed in the stock markets, which are very vulnerable to the developments. The low volatility hypothesis, which was a necessity for the "Carry Trade", has lost its validity and the negative developments in 
exchange rates have transformed the profit expectations into loss probability. Therefore, the foreign investors have started borrowing with small interest rates in developed country (especially in Japan) and started paying their high increase investments in developing countries. With the dissolution of carry trade investments in Turkey who was considered as one of the high profit markets, the Turkish Lira has lost $22 \%$ of its value in May. Besides the big currency account deficit and the increasing of the inflation have worried the foreign investors who thought Turkey might not achieve its targets because of the developments in external markets and fastened the capital outflow.

\section{What Kind of Capital Control Application and When to Apply It?}

The permanent control application to reduce the volatility in foreign capital movements seems like a reasonable approach. It is known by other countries' experiences that the long-term control applications are not effective and have a short-term effect. As the markets find somehow the ways to avoid the controls in long-term applications, it is necessary to put the restrictions in service with a proactive approach. Today the generally accepted approach is to put some restrictions on the capital inflows. Investment decisions by foreign capital are made with the knowledge about the variety of costs it has to occur, before entering a country. Introducing sudden restrictions on capital outflows without prior notification will impose (additional) costs on investors that are not taken into account, causing panic and crisis - if restrictions on outflows are announced previously -, what is more, adverse impacts on investors' willingness to invest in the country in the following periods. Thus, introducing controls on capital inflows rather than outflows seems to be a more suitable approach.

To be able to gain stability on capital inflows and reduce the volatility, the controlling authorities must proactively interfere in the market.

\section{Rule 1:}

The controls can start on periods where the short-term speculative capital inflow is one standard deviation above the average and they can be stopped when the capital inflow is below half standard deviation level of the average. Thus, the volatility in capital inflows will be smoothened.

When the best control application times were studied according to the suggested method, the dates indicated in the Table 9 come forward.

When Rule 1 is applied to largely defined capital by using annual moving averages and volatilities are determined 20 periods, by using biannual moving averages and volatilities are determined 12 periods, when Rule 1 is applied to narrowly defined capital by using annual moving averages and volatilities are determined 17 periods and by using biannual moving averages and volatilities are determined 12 periods.

Another criterion that should be taken into account is about ensuring the amount of capital inflow, computed according to Rule 1, reaching a specified proportion of GDP. On the occasions when reaching a specified proportion of GDP is not taken into account decisions are only made on the basis of volatility, it is bound to have been used a highly restrictive method on capital inflows and this might cause the total flight of the foreign capital from the country. Therefore, a new condition should be stipulated alongside Rule 1 .

Rule 2:

The foreign capital inflows should exceed the $2 \%$ of the previous quarter GDP.

Dates providing Rule 2 during the study period are indicated in Table 10.

Table 9. Periods providing Rule 1

\begin{tabular}{llll}
\hline Large Definition & & Narrow Definition & \\
\hline (Annual) & (Biennial) & (Annual) & (Biennial) \\
\hline September 96 & December 96 & December 96 & December 96 \\
December 96 & July 97 & July 97 & July 97 \\
July 97 & February 98 & February 98 & March 98 \\
October 97 & March 98 & May 98 & March 99 \\
April 98 & April 98 & June 98 & November 99 \\
May 98 & May 98 & March 99 & December 99 \\
June 98 & June 98 & November 99 & Danuary 00 \\
March 99 & November 99 & January 00 & June 00 \\
November 99 & December 99 & & \\
\hline
\end{tabular}




\begin{tabular}{|c|c|c|c|}
\hline December 99 & June 00 & June 00 & July 00 \\
\hline June 00 & July 00 & July 00 & August 00 \\
\hline July 00 & August 00 & August 00 & January 01 \\
\hline August 00 & December 00 & March 02 & October 02 \\
\hline December 00 & February 02 & May 02 & January 03 \\
\hline May 01 & January 03 & October 02 & August 03 \\
\hline August 01 & August 03 & January 03 & September 03 \\
\hline February 02 & September 03 & August 03 & December 03 \\
\hline January 03 & December 03 & September 03 & January 04 \\
\hline August 03 & January 04 & December 03 & December 04 \\
\hline September 03 & June 05 & January 04 & January 05 \\
\hline December 03 & July 05 & December 04 & \\
\hline January 04 & December 05 & January 05 & \\
\hline August 04 & January 06 & December 05 & \\
\hline January 05 & February 06 & January 06 & \\
\hline June 05 & & February 06 & \\
\hline July 05 & & September 06 & \\
\hline December 05 & & October 06 & \\
\hline January 06 & & February 07 & \\
\hline \multicolumn{4}{|l|}{ February 06} \\
\hline December 06 & & & \\
\hline
\end{tabular}

Table 10. Periods providing Rule 2 and their ratio to the GDP

\begin{tabular}{|c|c|c|c|c|c|c|c|}
\hline Large definition & $\begin{array}{l}\text { Ratio to } \\
\text { GDP (\%) }\end{array}$ & $\begin{array}{l}\text { Narrow } \\
\text { Definition }\end{array}$ & $\begin{array}{l}\text { Ratio to } \\
\text { GDP (\%) }\end{array}$ & Large definition & $\begin{array}{l}\text { Ratio to } \\
\text { GDP (\%) }\end{array}$ & $\begin{array}{c}\text { Narrow } \\
\text { Definition }\end{array}$ & $\begin{array}{l}\text { Ratio to } \\
\text { GDP (\%) }\end{array}$ \\
\hline April 96 & 4.01 & April 96 & 3.96 & January 05 & 4.60 & & \\
\hline June 96 & 3.22 & June 96 & 3.17 & April 05 & 2.31 & & \\
\hline August 96 & 2.05 & September 96 & 2.42 & June 05 & 7.64 & & \\
\hline September 96 & 3.69 & July 97 & 2,87 & July 05 & 4.79 & & \\
\hline December 96 & 2.21 & February 98 & 2.88 & September 05 & 2.97 & & \\
\hline May 97 & 2.91 & May 98 & 2.86 & November 05 & 2.14 & & \\
\hline June 97 & 2.52 & March 99 & 3.10 & December 05 & 6.58 & & \\
\hline July 97 & 4.18 & November 99 & 3.11 & January 06 & 6.64 & & \\
\hline September 97 & 2.39 & December 99 & 3,34 & February 06 & 6.12 & & \\
\hline October 97 & 2.58 & January 00 & 3.31 & March 06 & 2.09 & & \\
\hline February 98 & 2.84 & March 00 & 3.17 & June 06 & 2.80 & & \\
\hline March 98 & 2.30 & June 00 & 3.91 & August 06 & 3.05 & & \\
\hline April 98 & 4.59 & July 00 & 5.46 & September 06 & 3.89 & & \\
\hline May 98 & 4.58 & August 00 & 3.63 & October 06 & 3.71 & & \\
\hline June 98 & 2.51 & January 01 & 2.63 & December 06 & 6.77 & & \\
\hline March 99 & 2.73 & January 03 & 3.38 & February 07 & 3.09 & & \\
\hline August 99 & 2.04 & June 03 & 2.61 & March 07 & 4.86 & & \\
\hline November 99 & 3.47 & August 03 & 2.45 & April 07 & 2.67 & & \\
\hline December 99 & 4.45 & September 03 & 3.95 & May 07 & 5.89 & & \\
\hline January 00 & 3.31 & December 03 & 2.53 & June 07 & 4.54 & & \\
\hline March 00 & 3.56 & January 04 & 3.21 & & & & \\
\hline June 00 & 7.33 & June 04 & 2.20 & & & & \\
\hline July 00 & 7.34 & August 04 & 3.32 & & & & \\
\hline August 00 & 4.71 & December 04 & 2.58 & & & & \\
\hline December 00 & 6,88 & January 05 & 5.14 & & & & \\
\hline January 01 & 2.31 & June 05 & 3.15 & & & & \\
\hline May 01 & 6.20 & July 05 & 3.18 & & & & \\
\hline August 01 & 4.12 & September 05 & 2.13 & & & & \\
\hline December 01 & 2.70 & December 05 & 2.68 & & & & \\
\hline February 02 & 7.06 & January 06 & 2.11 & & & & \\
\hline
\end{tabular}




\begin{tabular}{|c|c|c|c|c|c|c|c|}
\hline Large definition & $\begin{array}{l}\text { Ratio to } \\
\text { GDP (\%) }\end{array}$ & $\begin{array}{l}\text { Narrow } \\
\text { Definition }\end{array}$ & $\begin{array}{l}\text { Ratio to } \\
\text { GDP (\%) }\end{array}$ & Large definition & $\begin{array}{l}\text { Ratio to } \\
\text { GDP (\%) }\end{array}$ & $\begin{array}{c}\text { Narrow } \\
\text { Definition }\end{array}$ & $\begin{array}{l}\text { Ratio to } \\
\text { GDP }(\%)\end{array}$ \\
\hline March 02 & 2.32 & February 06 & 4.33 & & & & \\
\hline July 02 & 3.11 & September 06 & 2.80 & & & & \\
\hline January 03 & 3,47 & October 06 & 3.48 & & & & \\
\hline August 03 & 2.78 & February 07 & 3.06 & & & & \\
\hline September 03 & 4.24 & & & & & & \\
\hline December 03 & 3.24 & & & & & & \\
\hline January 04 & 3.28 & & & & & & \\
\hline April 04 & 2.52 & & & & & & \\
\hline June 04 & 2.29 & & & & & & \\
\hline August 04 & 4.30 & & & & & & \\
\hline December 04 & 2.31 & & & & & & \\
\hline
\end{tabular}

The following periods providing both Rule 1 and Rule 2 on the retroactive study made to decide when to apply several controls on capital inflows were determined.

Table 11. Periods where the controls must be applied on capital inflow

\begin{tabular}{|c|c|c|c|}
\hline \multicolumn{2}{|l|}{ Large Definition } & \multicolumn{2}{|c|}{ Narrow Definition } \\
\hline (Annual) & (Biannual) & (Annual) & (Biannual) \\
\hline September 96 & December 96 & July 97 & July 97 \\
\hline December 96 & July 97 & February 98 & February 98 \\
\hline July 97 & February 98 & May 98 & March 98 \\
\hline October 97 & March 98 & June 98 & March 99 \\
\hline April 98 & April 98 & March 99 & November 99 \\
\hline May 98 & May 98 & November 99 & December 99 \\
\hline June 98 & June 98 & December 99 & January 00 \\
\hline March 99 & November 99 & January 00 & June 00 \\
\hline November 99 & December 99 & June 00 & July 00 \\
\hline December 99 & June 00 & July 00 & August 00 \\
\hline June 00 & July 00 & August 00 & January 01 \\
\hline July 00 & August 00 & January 03 & January 03 \\
\hline August 00 & December 00 & August 03 & August 03 \\
\hline December 00 & February 02 & September 03 & September 03 \\
\hline May 01 & January 03 & December 03 & December 03 \\
\hline August 01 & August 03 & January 04 & January 04 \\
\hline February 02 & September 03 & December 04 & December 04 \\
\hline January 03 & December 03 & January 05 & January 05 \\
\hline August 03 & January 04 & December 05 & \\
\hline September 03 & June 05 & January 06 & \\
\hline December 03 & July 05 & February 06 & \\
\hline January 04 & December 05 & September 06 & \\
\hline August 04 & January 06 & October 06 & \\
\hline January 05 & February 06 & February 07 & \\
\hline \multicolumn{4}{|l|}{ June 05} \\
\hline \multicolumn{4}{|l|}{ July 05} \\
\hline \multicolumn{4}{|l|}{ December 05} \\
\hline \multicolumn{4}{|l|}{ January 06} \\
\hline \multicolumn{4}{|l|}{ February 06} \\
\hline December 06 & & & \\
\hline
\end{tabular}

An intense capital inflow in the country before the sudden stops can be observed when we examine Table 10 and Table 11. If the speed of the capital inflow could have been slowed down with several methods during these periods, then it would be possible to recover from the negations and crises occurring after the sudden stop 
periods.

The restrictions on the short-term foreign capital should not be automatically put in circuit if both of the above-mentioned rules are simultaneously provided. If the conditions determined by the method occur, the authorities must decide what kind of measure to apply and for how long by following closely the developments in the market.

\section{Which Controls to Apply? Some Suggestions}

The stock market operations are stopped in case of extreme volatility in order to slow down the market decrease and reduce the panic atmosphere. This system is called "circuit breaker". The circuit breaker logic in stock markets can also be used for short-term capital inflows. The rules mentioned in the previous section and imposing some restrictions on the inflows can be evaluated as circuit breaker criteria. If the capital inflow volatility surpasses a certain level (Rule 1) and if the capital inflow amount reaches a certain level of the GDP (Rule 2), imposing taxes on the new capital will act as a circuit breaker. Below are mentioned some control methods, which can be applied capital inflows. Those measures can be applied alone or together.

\section{$5.1 \operatorname{Tax}$}

It may be possible to impose some tax duty on the foreign exchange transactions and stock market operations to reduce the rate of return expected by the capital and to slow down the capital inflow.

\subsection{Invaluable Reserve Liability}

A control mechanism similar to this of Chile can be adopted to deter the short-term capital inflow (Cowan \& Gregorio, 2005). As blockage of a certain amount of the foreign capital inflow in an invaluable account in the Central Bank will function as a duty, the capital return will decrease. The authorities must evaluate the current situation before deciding on which kind of capital inflow they will apply the invaluable reserve liability. For example, if a remarkable development is in question in fixed income security from portfolio investments, then only some of the short-term capital inflow can be blocked in order to invest in the fixed income security. If a movement, which will increase the volatility, is observed in the foreign loans, then it can be requested to keep some of the abroad loans in an invaluable account in the Central Bank. The minimum period for this kind of capital flows to stay in the country must be determined to avoid the hiding of the short-term capital behind the direct foreign investments. The capital that wishes to leave the country before due time must be considered as a short-term capital and must be taxed in accordance with the invaluable reserve liability if the date is corresponding to the control application period.

\section{Conclusion}

Regarding their battle with the sudden stops, some countries have chosen to accept the IMF's support while others have preferred to reduce the effects of the crises by imposing restrictions on the capital movements. The Malaysian-type controls were trying to prevent the capital outflow while Chile-type controls were aiming to slow down the capital inflow. Even the most liberalist economists and institutions like IMF accept the problems of fast liberalization in the capital account and favor the Chile-type controls for some periods. The empirical studies have shown that the capital controls are effective only if their scope encompasses a broad range and if they are short-termed. Otherwise, the market participants discover the legal and illegal means to avoid the controls and leave the restrictions on the capital ineffective.

This study aimed to determine the sudden stops in Turkey between 1996 and 2009 and utilized the following criteria for this purpose:

i- The decrease in the capital flow during any month of the sudden stop period must be at least two standard deviation below the average.

ii- The sudden stop period begins with decrease in the capital flow at any month when it is at least one standard deviation below the average.

iii- The sudden stop period ends with increase in the capital flow change at any month is above at least one level below of one standard deviation of the average.

The sudden stop period starts when the second condition is met and ends when the third one is observed. Moreover, it is expected that the capital decrease satisfies the first condition at least once between those two dates. To include the negative effects of the sudden stops on the economy in the criteria, another condition is added which requires that the change in capital movement during the sudden stop period reaches a certain level of the GDP (3\% and $5 \%)$. 
Five sudden stop periods with providing all the above mentioned were identified. August 1998 with Russian crisis, November 2000 crisis starting with liquidity problems, the deepening February 2001 crisis, March 2003 period where 1 March resolution regarding sending troops to Iraq was refused by the Turkish Parliament and May 2006 with the global fluctuation come forward as sudden stop periods in Turkey.

The imposition of some controls during some sudden stop periods to reduce the volatility of the short-term capital, which will increase the cost of the capital in periods where the capital inflow starts surpassing the decided criteria, must be considered as a policy, which will stabilize the growth. The preventive measure against the capital inflow should not automatically be effective. The implementation time, scope and durations must be planned under the initiative of the authorities. This study suggests imposing restrictions on the foreign capital inflow only if two rules are provided. According to the first rule, the controls should be applied when the capital inflows are one standard deviation above the average and they should be stopped when the capital inflow is half standard deviation below the average. The second rule suggests that the capital inflow must reach at least $2 \%$ of the GDP for the first rule to be applied.

As the short-term foreign capital entering the country via financial markets and the banks constituting a very important part of the financial markets in Turkey, it is important to accentuate the fragility of the banking sector against the capital inflow. The maturity mismatch, the currency mismatch and all the risks, which might be resulted from the derivative instruments, must be determined correctly and the necessary measures should be taken. The intense competition between the banks may lead to a bad administration and undermining of the said risks by the banks. In this case, the effects of any internal and/or external shock would be very substantial.

The capital controls are just short-term measures and they are not enough by themselves. In the long term, it is necessary to apply reasonable and responsible macroeconomic policies to reduce the volatility in the capital flow and a better governance as well as stronger institutions is needed. The economy will be strengthened and the vulnerability against the crises will be decreased only if these conditions are provided.

\section{References}

Arteta, O. C. (2003). Are financially dollarized countries more prone to costly crises? Board of Governors of the Federal Reserve System International, Financial Discussion Paper, 763.

Calvo, G. A., \& Reinhart, C. M. (2001). Fixing for your life. In S. M. Collins, \& D. Rodrik (Eds.), Brookings Trade Forum. Washington DC: Brookings Institution Press.

Calvo, G. A. (1998). Capital flows and capital-market crises: The simple economics of sudden stops. Journal of Applied Economics, 1(1), 35-54.

Calvo, G. A. (2005). Crises in emerging market economies: A global perspective. NBER Working Paper Series, 11305. http://dx.doi.org/10.3386/w11305

Calvo, G. A., Izquierdo, A., \& Mejia, L. F. (2004). On the empirics of sudden stops: The relevance of balance-sheet effects. NBER Working Paper, 10520. http://dx.doi.org/10.3386/w10520

Central Bank of Republic of Turkey. (2007). Balance of Payment Statistics, Definition, Principles and Practice in Turkey. Statistics Department, Balance of Payment Division.

Cowan, K., \& Gregorio, J. D. (2005). International borrowing, capital controls and the exchange rate: Lessons from Chile. NBER Working Paper, 11382. http://dx.doi.org/10.3386/w11382

Cowan, K., Gregorio, J. D., Micco, A., \& Neilson, C. (2008). Financial diversification, sudden Stops, and sudden starts. In K. Cowan, S. Edwards, \& R. Valdes (Eds.), Current Account and External Financing, Analysis and Economic Policies Series (Vol. 12, pp. 159-194). Central Bank of Chile.

Dornbusch, R., Goldfajn, I., \& Valdes, R. O. (1995). Currency crises and collapses. Brookings Papers on Economic Activity, 2, 219-293. http://dx.doi.org/10.2307/2534613

Edward, S. (2005). Capital controls, sudden stops and current account reversals. NBER Working Paper Series, 11170. http://dx.doi.org/10.3386/w11170

Frankel, J. A., \& Cavallo, E. A. (2004). Does openness to trade make countries more vulnerable to Sudden Stops, or Less? Using gravity to establish causality. NBER Working Paper Series, 10957. http://dx.doi.org/10.3386/w10957

Guidotti, P. E., Sturzenegger, F., \& Villar, A. (2004). On the Consequences of Sudden Stops. Economia, 4(2), 171-214. http://dx.doi.org/10.1353/eco.2004.0016

Hutchison, M., \& Noy, I. (2006). Sudden stops and the Mexican Wave: Currency crises, capital flow reversals 
and output loss in emerging markets. Journal of Development Economics, 79, 225-248. http://dx.doi.org/10.1016/j.jdeveco.2004.12.002

International Monetary Fund. (2006). Financial Market Update, June 2006.

International Monetary Fund. (2003). IMF Survey, 17 March 2003.

International Monetary Fund. (2007). Turkey: Financial System Stability Assessment, Country Report, No: 07/361, November 2007.

Rothenberg, A. D., \& Warnock, F. E. (2006). Sudden flight and true sudden stops. NBER Working Paper Series, 12726. http://dx.doi.org/10.3386/w12726

Stiglitz, E. J. (2002). Globalization and its discontents. W.W. Norton \& Company.

\section{Notes}

Note 1. Guillermo A. Calvo and Carmen M. Reinhart, (2001). Fixing for your life. In S. M. Collins, \& D. Rodrik (Eds.), Brookings Trade Forum. Washington DC: Brookings Institution Press.

Note 2. Some researchers claim that the big current deficit of the United States of America does not constitute a threat and it is not even a real deficit.

Note 3. The explanation of lack of fiscal discipline made for the 1980s South America debt crisis is insufficient to explain the crisis, which started in South East Asian countries. For example, the pre-crisis public debt rate to the GDP of Korea -one of the countries suffering from the crisis- was around $10 \%$, which is much less than many developed countries.

Note 4. It is suggested that the countries, which aimed an unsustainable exchange rate peg, suffer from balance of payment crisis if they do not renounce to this policy on time. However, this suggestion is not enough to explain the real meltdown like the production and unemployment.

Note 5. Central Bank of Republic of Turkey CBRT, (2007). Balance of Payment Statistics, Definition, Principles, and Practice in Turkey. Statistics Department, Balance of Payment Division, p. 21.

Note 6. CBRT, op.cit. p. 22.

Note 7. CBRT, op.cit. p. 23.

Note 8. The three months GDP figure of the said month was used.

Note 9. IMF, Financial Market Update, June 2006.

\section{Copyrights}

Copyright for this article is retained by the author(s), with first publication rights granted to the journal.

This is an open-access article distributed under the terms and conditions of the Creative Commons Attribution license (http://creativecommons.org/licenses/by/3.0/). 